\title{
IMPROVISASI DALAM TEATER: ANTARA TEKNIK PEMERANAN DAN PERTUNJUKAN
}

\author{
Eko Santosa \\ PPPPTK Seni dan Budaya Yogyakarta
}

\begin{abstract}
Abstrak: Improvisasi terkadang sulit untuk didefinisikan. Setiap pekerja seni teater memiliki konsep, metode dan cara mereka sendiri untuk melakukannya. Namun dari semuanya, improvisasi selalu terkait dengan spontanitas yang ditransformasikan dari konsep acting is doing. Ketika akting adalah reality of doing maka akan ada gerakan fisik yang membawa pengaruh pada perasaan atau emosi. Untuk memiliki adaptasi fisik spontan dalam setiap adegan akting, aktor harus dilatih dengan baik dalam hal improvisasi. Materi pelatihan improvisasi berisi semua elemen akting yang mengikuti empat aturan: why, do's, dont's, and how. Aktor yang memiliki keterampilan improvisasi dapat membawa elemen-elemen tersebut kepada realitas akting sebagai suatu teknik dalam teater yang berbasis naskah atau untuk tampil dalam suatu teater improvisasi.
\end{abstract}

Kata kunci: improvisasi, teknik akting, pertunjukan, latihan

\begin{abstract}
Improvisation is sometimes hard to be defined. Every theater worker has their own concept, methode and way to do it. But must of all, improvisation is always connected to spontanity which is transformed from acting is doing. When acting is reality of doing there would be a physical action which brings influence to feelings or emotions. To have a spontaneus physical adaptation in every beat of scene of acting, actors should be well trained in the term of improvisation. The training materials of improvisation contains all elements of acting which are following four rules: why, do's, dont's, and how. Actors whom have skill of improvisation could bring it into the reality of acting as a technique in script's based theater or to perform within theater improvisation.
\end{abstract}

Key words: improvisation, acting technique, performance, training

\section{Pendahuluan}

Improvisasi menurut John Caird (2010) dapat disebut sebagai seni drama tanpa persiapan. Senada dengan hal itu, Rendra (2013) menyebut improvisasi sebagai ciptaan spontan seketika itu juga. Dasar pemikiran Viola Spolin dalam mengembangkan pelatihan improvisasi juga dibentuk dari pentingnya spontanitas sebagai momen kebebasan personal pemeran ketika berhadapan dan menyaksikan langsung kenyataan, mengeksplorasi untuk kemudian dijadikan acuan dalam menyesuaikan laku aksinya (Spolin, 1999). Spontanitas tindakan atau laku aksi pemeran di atas pentas didasari pada kebutuhan untuk berperan pada "saat ini" yang secara piawai diformulasikan oleh Stanislavski (2003) ke dalam teknik laku jasmani (technique of physical actions) dan secara umum dikenal sebagai acting is doing. Keadaan "saat ini" atau sering disebut dengan "being in the moment"adalah aksi yang dilakukan oleh pemeran tepat pada saat aksi itu benar-benar diperlukan sehingga 
pemeran benar-benar tidak memiliki tujuan lanjut yang direncanakan setelah aksi tersebut dilakukan (Book, 2002). Pemahaman dan penguasaan atas keadaan ini membawa pemeran ke dalam pemeranan spontan dan natural. Kondisi "saat ini"dalam lakon dapat dipahami melalui aksi jasmani yang berubah atau beradaptasi secara segera atas satu peristiwa dengan tanpa mempersiapkan penataan perasaan atau emosi sebelum bertindak. Segala perasaan (tanpa perlu dipersiapkan) akan muncul dengan sendirinya sebagai akibat dari aksi yang dilakukan. Laku aksi pemeran di atas pentas dimana perasaan telah dipersiapkan sebelum bertindak akan menghasilkan pemeranan artifisial sehingga terlihat tidak alami. Untuk menghindari hal itu diperlukan spontanitas perubahan physical actions sebagai rangkaian aksi-reaksi dalam satu peristiwa lakon. Keadaan tanpa persiapan atau spontan ini kemudian digunakan untuk memaknai improvisasi dalam teater.

Walaupun terdapat situasi yang terlihat paradoks dalam improvisasi. Term improvisasi mensyaratkan pencarian dan kreativitas spontan, namun dalam aplikasinya hal ini terbukti berhasil ketika lebih dahulu dipersiapkan dengan baik dan penerapannya terkontrol serta terbimbing (Caird, 2010). Jadi, untuk melakukan aksi spontan di atas panggung pemeran perlu dilatih. Seringkali sutradara atau pelaku teater kurang mendalam dalam mempelajari dan menerapkan improvisasi sehingga menghasilkan sesuatu di luar harapan. Seolah terjebak pada makna dasar spontan sehingga tidak perlu menyediakan persiapan-persiapan melalui program pelatihan. Improvisasi tentu tidak bisa sembarang dilakukan tanpa memahami aturan ataupun teknik penerapannya. Tidak bisa pula dikerjakan tanpa latihan sesuai dengan alasan dan tujuan.

Alasan dan tujuan dilakukan atau dilatihkannya improvisasi berbeda antara pelaku teater satu dengan yang lain. Dari berbagai alasan dan tujuan, juga disertai studi penerapan improvisasi dalam pertunjukan, Jeanne Leep (2008) merumuskan improvisasi menjadi 3 alasan/tujuan utama; 1) improvisasi sebagai sebuah pertunjukan mandiri, 2) improvisasi sebagai piranti (tools) aktor, dan 3) improvisasi sebagai proses drama atau piranti bagi non-aktor. Dua tujuan awal improvisasi di atas dipilih menjadi pokok bahasan dalam tulisan ini karena memiliki keterkaitan langsung dengan subjek pemeranan dan pertunjukan teater. Tujuan improvisasi sebagai pertunjukan sudah umum diketahui dan banyak ditampilkan terutama oleh teater tradisional. Sementara Improvisasi sebagai piranti aktor diajarkan sebagai bagian dari teknik bermain peran di akademi atau sekolah khusus teater.

Terkait dengan improvisasi sebagai pertunjukan, pandangan umummenyatakan bahwa pertunjukan teater improvisasi adalah pertunjukan teater tanpa teks. Pandangan ini lumayan tegak bertahan bagi sebagian pelaku teater, sehingga (seolah) tidak memungkinkan seseorang melakukan improvisasi dalam pertunjukan teater berbasis teks. Kalaupun pemeran tersebut melakukannya, maka ia dapat dianggap merusak konsep pertunjukan karena biasanya improvisasi dilakukan dengan menambah atau mengurangi baris kalimat dialog pada saat dipentaskan. Pun demikian dalam pertunjukan teater yang dianggap sebagai improvisasi - teater tradisional misalnyayang terjadi adalah baris-baris kalimat dialog yang disampaikan secara lisan oleh sutradara dalam proses latihan telah terlebih dahulu dihafal sehingga mengaburkan makna spontanitas ketika dipentaskan. Para pemeran teater tradisional sebenarnya bisa dikatakan tidaklah berimprovisasi karena semua baris kalimat dialog yang menjadi bagiannya telah dihafal luar kepala sehingga kapanpun cerita itu dipentaskan kalimat dialognya tetap. Padahal spontanitas selalu menggambarkan 
sesuatu yang segar, baru, dan orisinal persis seperti makna "saat ini" dalam pemeranan. Menilik kondisi ini, sangat menarik kiranya membahas improvisasi sebagai teknik pemeranan (peranti aktor) dan pertunjukan. Keduanya bisa saling bersinggungan di mana pertunjukan teater improvisasi memerlukan aktor yang memahami penerapan teknik improvisasi sehingga tidak kehilangan makna spontanitas dalam sajian pemeranannya. Pun bisa pula dalam singgungan di mana aktor berlatih improvisasi untuk diterapkan dalam teater berbasis teks sebagai salah satu teknik berperan. Singgungan-singgungan ini akan dijabarkan dalam bahasan improvisasi sebagai teknik pemeranan (dalam teater berbasis teks) dan improvisasi sebagai pertunjukan berikut.

\section{Improvisasi Sebagai Teknik Pemeranan}

Sutradara dan pelatih teater menggunakan latihan improvisasi untuk meningkatkan kemampuan berperan para pemainnya. Rendra (2013) menyatakan bahwa latihan improvisasi berguna untuk melatih daya cipta aktor yang didasari keyakinan dengan menghilangkan rasa malu dan menghapus prasangka akan celaan yang bakal diterima. Namun Rendra tidak menjelaskan secara khusus cara menghilangkan rasa malu dan prasangka celaan sebelum melakukan latihan improvisasi. Dengan demikian syarat dasar itu harus telah dimiliki pemeran ketika hendak melakukan latihan improvisasi ini. Rendra membagi latihan improvisasi ke dalam improvisasi solo, dengan perabotan, dengan pasangan, dengan rangka cerita, dan menanggapi bunyi dan musik. Latihan dilakukan berdasarkan instruksi-instruksi pendek pelatih yang sengaja diberikan untuk merangsang pikiran. Fokus Rendra dalam latihan improvisasi adalah tumbuh kembangnya daya khayal pemeran. Ia tidak secara khusus membicarakan laku aksi spontan. Bahkan ia menyarankan para pemeran agar membulatkan alasan pikiran dan perasaan sebelum berucap. Tujuan akhir dari latihan improvisasi ini adalah lahirnya pesona pemeran melalui aksi yang mengandung daya cipta dan khayal. Latihan improvisasi Rendra ini lebih mengacu pada pola pementasan atau pemeranan teater tradisional dan tidak secara khusus mengolah teknik improvisasi pemeran dalam teater berbasis teks, meskipun diketahui bahwa pertunjukan teater Rendra lebih banyak berbasis teks daripada non-teks.

Penekanan latihan improvisasi untuk menggali spontanitas pemeran diperlihatkan oleh Sanford Meisner. Jauh sebelum memasuki dunia teks, Meisner membekali muridnya dengan dasar-dasar bermain peran. Hal pertama yang dipahamkan adalah bahwa pemeranan merupakan laku aksi nyata. Orang dikatakan berperan hanya jika aksi yang ia kerjakan nyata, tidak dibuat-buat. Berikutnya pemahaman mengenai naluri yang dijelaskan melalui ekspresi spontan ketika seseorang dihadapkan pada perubahan keadaan tiba-tiba. Berikutnya penegasan mengenai aksi nyata tanpa pretensi di mana saat aksi dilakukan semua perasaan dan pikiran menyatu di dalam tindakan. Jadi, tidak diperkenankan menyertakan perasaan atau pikiran sebelum tindakan. Selanjutnya terkait langsung dengan spontanitas dan naturalitas permainan, latihan yang dilakukan adalah pengulangan kata atau kalimat dalam adegan. Selepas memahami dasar-dasar ini, pemeran dipersiapkan untuk menghadapi teks. Sesi latihan ini terdiri dari memori dan imajinasi, improvisasi untuk menjelaskan relasi antarperan dan pembangunan cerita, serta kecepatan berpikir. Semua sesi latihan ini dikerjakan tanpa teks. Meisner memberikan keterangan, pertanyaan, penjelasan, adegan, dan arahan secara lisan (lihat Meisner, Longwell, \& Pollack, 1987).

Meisner tidak memberikan tuntunan secara langsung mengenai teknik improvisasi 
dengan teks sebagai sebuah teknik pemeranan, melainkan unsur-unsur improvisasi yang perlu dimiliki oleh aktor dalam menghadapi teks. Misalnya, dalam latihan pengulangan, spontanitas dan naturalitas permainan benar-benar digali melalui adegan improvisasi. Kata atau kalimat pengulangan dipaksa untuk dimunculkan hingga akhirnya terucap secara otomatis (spontan) dan intuitif, terkesan alami tanpa rekaan. Ketika pemeran berhasil memahami makna latihan improvisasi pengulangan ini, maka spontanitas aksi dapat diwujudkan. Lakuan spontan memerlukan keterbukaan diri di mana pemeran tidak diperkenankan untuk mempersiapkan dirinya beraksi melainkan bersiap untuk menerima. Aktivitas menerima ini akan mendayakan seluruh kelengkapan pemeranan yang dimiliki dan membuatnya bertindak balik secara intuitif. Untuk keperluan itulah latihan pengulangan dilakukan sehingga tindak memberi dan menerima menjadi alami. Pemahaman ini penting bagi pemeran sehingga kemudian ia benar-benar bisa meninggalkan pola latihan pengulangan dan mampu menahan dirinya beraksi sampai muncul sesuatu yang menggerakkannya untuk beraksi ketika bermain peran (Esper \& DiMarco, 2008).

Latihan-latihan improvisasi melalui adegan untuk memaksimalkan kemampuan pemeran populer sebagai model. Penggalpenggal adegan improvisasi bahkan diciptakan secara khusus untuk tujuan peningkatan kemampuan tertentu. Viola Spolin merupakan salah satu pionir dalam hal latihan improvisasi. Ia mencetuskan berbagai adegan untuk memberdayakan potensi diri pemeran dalam bermain peran. Ia mendasari adegan-adegan tersebut dengan bentangan konsep mengenai game (permainan), approval / disapproval (setuju / tidak setuju), group expression (ekspresi kelompok), audience (penonton), theatre technique (teknik teater), carrying the learning process into daily Life (mengusung proses pembelajaran ke dalam kehidupan seharihari), physicalization (menubuhkan). Game merupakan bentuk kegiatan kelompok alamiah yang menyediakan pelibatan dan pembebasan pribadi yang diperlukan dalam mengasah pengalaman. Melalui game ini teknik dan kemampuan personal seseorang terasah. Approval/disapproval merupakan cermin budaya di mana terdapat nilai pantas dan tidak pantas dalam berlaku. Dengan saling terbuka dan menerima, maka seseorang yang terbatasi dirinya oleh "pantas/tidak pantas" dapat membebaskan diri dan perasaannya sehingga leluasa berekspresi. Group expression, hubungan antar person dalam sebuah kelompok yang sehat akan memampukan semua orang untuk saling berpartisipasi dan berkontribusi. Audience, memberikan pemahaman akan pentingnya penonton dalam sebuah pertunjukan teater. Tanpa penonton tidak ada teater. Theatre technique, memberikan kesadaran untuk menjauhkan dari prasangka bahwa teknik teater adalah sesuatu yang sakral hingga sulit diajarkan. Teknik teater pada dasarnya adalah teknik berkomunikasi dan keterpahaman akan komunikasi jauh lebih penting dari pada metodenya. Carrying the learning process into daily Life, satu proses latihan untuk meningkatkan kemampuan pemeran menghadirkan kenyataan di atas pentas. Physicalization, melatihkan kemampuan non-verbal pemeran melalui kebebasan ekspresi fisik sebagai lawan dari pendekatan intelektual dan psikologi dalam berkomunikasi (Spolin, 1999). Semua jenis latihan Spolin dimaksudkan untuk mempersiapkan kelengkapan diri pemeran, bukan untuk langsung memainkan peran. Jadi semua adegan yang ada tidak menggunakan cuplikan naskah lakon. Bahkan dalam produksi teater, improvisasi merupakan latihan penting yang dilakukan selama proses produksi namun materi latihan tidak bisa 
dicuplikkan dari baris-baris kalimat dialog yang akan dimainkan. Selain tidak berguna, fase latihan improvisasi difungsikan untuk menjauhkan pemeran dari rasa keterpenjaraan akan teks. Latihan improvisasi seharusnya membawa pemeran ke dalam pemikiran dan habitus baru (di luar lakon) sehingga dapat menghindari klise pengucapan dialog verbal dari teks lakon (lihat Cohen, 2010).

Paparan model-model latihan improvisasi di atas meskipun diperuntukkan bagi pemeran, tidak sepenuhnya mengarah langsung kepada improvisasi sebagai teknik pemeranan dalam teater berbasis teks. Materi-materi yang disediakan bahkan tidak diperkenankan menyuplik baris kalimat dialog lakon. Pemeran dalam konteks ini hanya dibekali piranti pemeranan yang dapat diterapkan ketika bermain peran melalui serangkaian latihan improvisasi. Seolah menjawab kegelisahan tersebut, Stephen Book (2002) terinspirasi karya Spolin mengembangkan improvisasi sebagai teknik pemeranan dan secara langsung bersentuhan dengan teks lakon. Meski latihan-latihan adegan tanpa teks tetap disertakan sebagai persiapan pemeran namun tujuan utama Book adalah pemeran dapat menerapkan teknik improvisasi dalam teater (film dan televisi) berbasis teks.

Terkait improvisasi dalam teater berbasis teks, Book menyebutkan 2 macam improvisasi yaitu improvisasi tradisional dan teknik improvisasi. Dalam improvisasi tradisional terdapat 2 gaya yaitu pemeran mengubah given cirumstances (kondisi atau keadaan yang diberikan oleh pengarang di dalam peristiwa lakon) dan pemeran mengubah dialog. Pengubahan given cirumstances dilakukan semasa latihan untuk meningkatkan intensitas dan energi permainan. Misalnya dalam sebuah adegan lamaran, pemeran menurut lakon melamar kekasihnya karena cinta. Untuk membangkitkan intensitas, pemeran melakukan improvisasi dengan mengubah fakta bahwa ia melamar karena uang, sebagai konsekuensinya intonasi kalimat berubah. Pengubahan ini akan serta-merta berdampak kepada lawan main dan membuat adegan terlihat berbeda meski baris kalimat dialog tetap sama. Namun demikian, hal tersebut hanya dilakukan saat latihan dan ketika pementasan kembali pada yang diberikan pengarang. Gaya kedua, pemeran mengubah beberapa bagian kalimat dialognya sebelum lepas naskah ketika sesi eksplorasi struktur adegan, motivasi karakter, dan makna adegan. Pengubahan ini dilakukan untuk menghindari jeda menunggu cue, mencairkan dialog yang kaku, dan mengasumsikan apa yang sedang terjadi atau makna dialog yang diucapkan. Pengubahan secara improvisasi ini akan membantu pemeran memahami dan mengingat baris kalimat dialog. Namun, ketika pementasan semua kembali ke lakon sepenuhnya. Hal ini berbeda sekali dengan teknik improvisasi yang dibangun berdasarkan konsep "acting is doing". Kata "doing" menggambarkan pemeran fokus pada keadaan fisik dan energi psikologis terhadap peristiwa. Teknik improvisasi terkonsentrasi pada perubahan aktivitas fisik bukan pada kerja pikiran. Jika kondisi atau keadaan berubah, tubuh akan segera melakukan penyesuaian dan selalu berada pada "saat ini" sehingga tidak memiliki perkiraan aktivitas atau tujuan berikutnya. Dalam teknik improvisasi, pikiran pemeran terbebas dari memikirkan tindakan berikutnya. Pikiran fokus pada apa yang dilakukan oleh tubuh saat itu juga (Book, 2002).

Level pertama teknik improvisasi dapat dilakukan dengan menentukan dan menerapkan fokus tindakan dalam sebuah adegan berbasis teks. Fokus tindakan merupakan elemen pemeranan yang terdiri dari fisik, vokal, dan inner (diri dalam). Cobaan pertama, pemeran diminta memainkan adegan sesuai dengan karakter, 
aktivitas, dan lokasi. Pemeran diperbolehkan melakukan improvisasi sesuai fokus tindakan yang dipilih. Cobaan kedua, adegan diulangi lagi namun dengan fokus tindakan yang ditentukan oleh pelatih. Cobaan ketiga, adegan kembali diulang namun pemeran diminta untukmembebaskan tubuhnya untuk menjalani semua adegan, membebaskan pikiran dan membiarkan tubuh mengikuti impuls yang ada. Setelah selesai pemeran diminta untuk mengungkapkan impresinya atas cobaan pertama dan ketiga. Umumnya, pemeran akan merasa terbebaskan laku perannya pada cobaan ketiga. Hal ini dikarenakan pada cobaan pertama membuka kemungkinan pencarian bagian-bagian tindakan yang tidak terpikirkan sebelumnya. Cobaan kedua, improvisasi akan mengarahkan pada dunia spontanitas. Cobaan ketiga memfilter tindakan yang dianggap tidak autentik tanpa disadari (Book, 2002). Level pertama ini memberikan pemahaman kepada pemeran bahwa fokus tindakan bukanlah tindakan (fisik, vokal, inner) yang dikerjakan dengan dipikirkan namun dilakukan mengalir sesuai impuls jasmani dalam melakoninya. Setiap perubahan jasmani akan secara otomatis diikuti elemen lainnya.

Setelah fokus tindakan dipahami, selanjutnya Book memberikan metode penerapan teknik improvisasi dalam pemeranan berbasis teks. Metode ini didasari pada pemikiran bahwa esensi pemeranan adalah menciptakan karakter, menentukan pilihan dan memainkan pilihan tersebut secara spontan. Penentuan pilihan dimulai dari menemukan tujuan adegan yang akan dimainkan. Sebuah adegan tidak akan nampak hidup dimainkan jika tidak jelas tujuannya. Penemuan tujuan dalam adegan dilakukan dengan membedah adegan ke dalam 4 jenis beat (satuan tindakan terkecil) yaitu konflik (conflict), persetujuan (agreement), cerita (story), dan pengungkapan karakter (character revelation). Konflik merupakan beat yang mengandung perlawanan atas keinginan, kejiwaan, dan bernuansa suram. Persetujuan merupakan beat dimana para karakter bermain dan bekerja bersama secara komunal dengan kegembiraan, antusiasme, bergairah serta tidak saling menegasi. Cerita adalah beat yang berisi kejadian atau dialog yang secara signifikan menggerakkan plot atau dapat disebut juga sebagai pokok cerita. Sedangkan pengungkapan karakter adalah beat yang menunjukkan pernyataan emosi atau keadaan sikap sesungguhnya di balik kata-kata yang diucapkan tokoh (Book, 2002).

Pemeran harus membedah adegan yang akan dimainkan dan menandai bagianbagian adegan sesuai dengan 4 jenis beat tersebut. Masing-masing beat mengandung fokus tindakan yang perlu dilakukan. Setiap beat dan perubahan beat membawa konsekuensi perubahan atau adaptasi jasmani dalam bertindak. Setiap perubahan tindakan yang dilakukan karakter satu otomatis berpengaruh pada karakter lain. Jika semua karakter mengerjakan pembedahan sesuai metode ini, maka tampilan adegan akan terlihat hidup dan penuh spontanitas. Proses bedah adegan memerlukan waktu dan pembiasaan. Menandai kejadian sesuai dengan beat bukan perkara yang mudah namun itu merupakan salah satu syarat dalam penerapan teknik improvisasi. Ketika semua adegan dalam lakon dibedah, maka spontanitas tindakan dalam berperan akan nampak sepanjang lakon dimainkan dan dengan demikian penerapan teknik improvisasi berjalan baik. Metode yang ditawarkan Book ini memberikan penjelasan mengenai acting is doing dan bagaimana hal itu dilakukan melalui aksi fisik spontan.

\section{Improvisasi Sebagai Pertunjukan}

Sejarah teater improvisasi membentang panjang. Reportasi Aristoteles teantang teater tragedi dan komedi masa awal 
yang belum menggunakan naskah. Masa Yunani Kuno dan Romawi para aktor yang disebut sebagai mime menciptakan cerita mitologi dan tema-tema domestik. Zaman Renaissance menyumbang kemegahan dan kemeriahan Commedia dell 'arte yang pengaruhnya terasa sampai sekarang. Sejarah juga mencatat bahwa pertunjukan improvisasi pada masa itu bukan merupakan piranti keaktoran dalam hal spontanitas ataupun pengembangan karakter. Tujuantujuan di luar pertunjukan baru lahir pada pertengahan abad dua puluh melalui bentukbentuk kontemporer yang dimulai dari theater game-nya Viola Spolin (Leap, 2008). Melalui theater game, Spolin menyebarkan improvisasi ke dalam serangkaian latihan dengan pendekatan permainan. Ia menjembatani problem pemeranan yang seringkali muncul dalam teater remaja dan bahkan anak-anak. Spolin menjadikan pemeran sebagai sesuatu pengalaman pembelajaran yang menyenangkan sehingga teater menjadi sesuatu yang mengasyikkan untuk dipelajari (lihat Spolin, 1986).

Untuk menuju ke pertunjukan teater improvisasi, para pemeran harus memahami aturan atau cara berimprovisasi. Aturanaturan ini dikenal dan diterapkan melalui penggal adegan ataupun rangkaian aktivitas terstruktur. Secara umum aturan dasar improvisasi adalah; why, do's, don'ts, dan how. Why merupakan fokus atau tujuan dari penggal adegan atau permainan tersebut dilakukan. Do's adalah penawaran dialog atau tindakan oleh lawan main yang harus diterima atau diiyakan. Don'ts merupakan dialog atau tindakan untuk menolak tawaran yang diberikan. How adalah justifikasi yang dilakukan dengan cepat yang biasanya dibentuk dengan format "siapa menjadi apa/siapa dan di mana lokasi cerita dilangsungkan". Format ini akan membantu pemeran untuk segera menjustifikasi aktivitas yang dilakukan (Leap, 2008). Pemeran tidak diperbolehkan keluar dari aturan dasar ini sebab jika hal itu dilakukan justru akan membuat adegan tidak berkembang, tujuan adegan kabur, dan pemeran terjebak untuk lama berfikir sehingga sulit menjustifikasi aksinya.

Untuk mengembangkan dialog dan membantu pemeran cepat menanggapi latihan do's dilakukan dengan format "yes and..." di mana pemeran harus mengiyakan tawaran dialog temannya. Ia tidak boleh menolak. Ketika seorang pemeran menolak, maka kesatuan gagasan tidak terbentuk dan kelanjutan cerita akan menjadi sumir karena masing-masing pemain membawa gagasannya sendiri sehingga yang dilakukan adalah aksi-kontra aksi dan bukannya aksireaksi (Santosa, 2014). Pemeran yang tidak menerima tawaran telah melakukan block dan cerita tidak bisa berlanjut. Perhatikan contoh dialog berikut.
A: Ouh!!
B: Ada apa?
A: Aku memakai jaket terbalik.
B: Boleh aku lepaskan jaketmu?
A: Jangan!

Adegan menjadi berhenti dan sulit untuk diteruskan karena A melakukan block. A tidak mau menerima gagasan B untuk membantu melepaskan jaketnya dan atau berpura-pura melepas jaket bersama B dengan malu-malu. A dengan demikian telah mengecewakan harapan penonton (Johnstone, 2014). Dengan konsep "yes and...", pemeran akan terbiasa menghargai dialog lawan main dan cepat dalam menanggapi. Keterbukaan diri dalam menerima, menyerap, dan beradaptasi sangat diperlukan dalam hal ini.

Untuk melakukan block atas tawaran dialog atau tindakan, dalam aturan don'ts dilakukan dengan menggunakan format atau konsep "yes but...". Melakukan penolakan membutuhkan gagasan tersendiri sehingga kecepatan tanggapan sulit diwujudkan. Dengan format "yes but..." pemeran akan menerima gagasan lawan dialog tapi 
kemudian meneruskan topik pembicaraan dengan tawaran berlawanan yang diawali kata "tetapi". Latihan ini baik untuk memberikan gambaran kealamian spontanitas. Perhatikan contoh dialog berikut.

A: Maaf, apakah itu anjingmu?

B: Ya, tetapi aku akan menjualnya.

A: Apakah kau mau menjualnya padaku?

B: Ya, tetapi ini anjing mahal.

A: Apakah anjing ini sehat?

B: $\quad$ Ya, tetapi jika kau tak percaya bisa membawanya ke dokter dulu.

Seperti itulah strukur dialog yang terbentuk seterusnya. Jika dikerjakan dengan cepat dan bersemangat dengan tanpa banyak pertimbangan dalam menanggapi adegan akan menjadi sangat lain dan menarik (Johnstone, 2014).

Proses latihan do's dan don'ts dilakukan untuk menemukan bentuk alami spontanitas di mana terkadang logika dibaikan. Persis seperti ketika melihat seseorang terpeleset jatuh dan kita secara spontan tertawa. Tindakan menertawakan penderitaan orang lain tidaklah logis, namun begitulah kerja alami spontanitas. Dengan tujuan yang jelas (why) serta proses justifikasi (how) yang cepat, adegan atau permainan improvisasi akan berjalan dengan baik. Pemeran akan menemukan pemahaman ketika adegan selesai dilakukan. Untuk menegaskan sisi natural, Johnstone (2014) membeberkan konsep status dalam latihannya. Dimulai dari studi observasi pertunjukan yang nampak kaku dan tegang, Johnstone mengamati setiap karakter dan menemukan titik kelemahannya. Secara alami dalam kehidupan sehari-hari, dalam setiap pembicaraan, seseorang memiliki status lebih tinggi atau rendah dari lainnya yang diperlihatkan melalui cara, gaya atau kalimat yang diucapkannya. Pun demikian semestinya denga adegan di atas pentas. Ketika pemahaman ini diterapkan dalam latihan di mana setiap pemeran harus meninggikan atau merendahkan status dalam setiap pembicaraan, hasilnya adalah sesuatu yang autentik. Dalam proses latihan Johnstone kemudian, status ini ditempatkan sebagai awal pemahaman bagi pemeran.

Empat aturan dasar improvisasi dan pemahaman status tersebut menjadi roh dari setip permainan atau penggal adegan improvisasi. Semua pelatih teater improvisasi mentaati aturan tersebut. Latihan improvisasi harus dilakukan secara berterusan. Dengan latihan rutin dalam berbagai jenis adegan pemeran akan terlatih untuk menanggapi berbagai situasi. Selain untuk spontanitas, latihan improvisasi akan menghindarkan pemeran dari rasa tidak bisa, takut salah, kemandegan gagasan dengan berani mengambil risiko, tidak takut salah, menghindari penilaian diri, tidak gamang berlaku karena selalu menduga-duga, dan konsentrasi sehingga memiliki kecerdasan mental (Atkins, 1994). Setiap tahap latihan akan meningkatkan level kemampuan pemeran.

Setelah pemeran memiliki dasar-dasar improvisasi yang kuat, pertunjukan teater improvisasi bisa dilangsungkan. Bentuk kontemporer pertunjukan improvisasi terdiri dari short form (bentuk pendek), long form (bentuk panjang), dan sketch based (berdasar sketsa). Short form dapat disebut sebagai permainan improvisasi di mana adegan dibuat di tempat pementasan atas sugesti penonton. Long form dapat dikatakan sebagai lakon yang memiliki bagian awal, tengah, dan akhir atau rangkaian adegan yang diikat bersama dalam satu tema. Bentuk ini ditampilkan di atas panggung di mana para pemeran tidak tahu akhir dari cerita atau adegan akan terangkai kemudian setelah pertunjukan dimulai. Sketch based, merupakan rangkaian adegan pendek yang dikompilasi sedemikian rupa untuk tujuan pertunjukan hiburan (lihat Leap, 2008). Ketiga bentuk pertunjukan improvisasi ini 
sangat populer terutama short form dan sketch based dan telah mewarnai panggung teater.

Masing-masing bentuk memiliki strukturnya sendiri. Untuk memainkan tiga bentuk pertunjukan ini dan sebelum menuju struktur cerita, pemeran mesti memahami tiga aturan dasar dalam pertunjukan improvisasi. Dengan mengikuti aturan berikut ini, pemeran akan tampil baik; 1) Say the first thing that comes into your head atau ucapkan apa yang pertama melintas di pikiranmu, 2) Say, "Yes! And..." to all of your partner offers atau ucapkan "ya! Dan..." kepada semua teman main yang memberikan tawaran, dan 3) Make your partner look good atau buatlah lawan mainmu nampak indah (Diggles, 2004). Setiap pemeran harus mempercayai gagasan yang ada dalam pikirannya. Ia tidak diperkenankan ragu-ragu karena keraguan melahirkan ketidakjelasan informasi baik bagi penonton maupun lawan main. Berikutnya ketika gagasan sudah tersampaikan melalui kalimat dialog, gagasan tersebut harus dibangun bersamasama antara pemeran satu dengan yang lain. Dalam membangun gagasan bersama ini pemeran harus membuat pemeran lain nampak indah. Artinya, tawaran dialog atau tindakan lawan main harus diyakini kebenarannya untuk diterima.

Pertunjukan improvisasi merupakan kesetimbangan tetap antara spontanitas dan struktur. Keduanya merupakan kolaborator hebat. Penonton tidak hanya akan melihat spontanitas melainkan spontanitas yang terbentuk melalui imaji, adegan, lagu, tarian, soneta, pencarian bentuk yang bebas berdasar tema atau bentuk-bentuk spesifik lain dari khasanah seni pertunjukan (Adams, 2007). Artinya, spontanitas hanya akan terlihat melalui struktur penampilannya. Struktur long form paling menantang untuk dipentaskan (sementara struktur lain hampir menyerupai struktur adegan dalam latihan).
Apalagi ketika struktur ini mengambil format lakon penuh - seperti halnya dalam pertunjukan teater tradisional.

Kenn Adams (2007) mencoba memformulasikan struktur ini sebagai bagian (adegan) awal, kejadian siginifikan permulaan, tengah, kilmaks, dan akhir. Pada bagain awal berisi materi pemaparan berupa waktu, lokasi, karakter, dan konteks. Di sinilah pondasi cerita dibangun di mana terdapat rutinitas di dalamnya. Kondisi ini diakhiri dengan satu kejadian signifikan yang membuyarkan rutinitas tersebut. Kejadian ini tidak bisa dibatalkan dan akan membawa karakter dalam ketidakpastian atau menuju ke bagian tengah. Pemeran pada bagian ini harus melawan kondisi yang ada dan berjuang untuk menggapai kesuksesan. Dalam perjuangan selalu terdapat dua pilihan yaitu gagal atau berhasil. Ketetapan untuk terus berjuang dengan risiko gagal atau berhasil ini menandakan bagian kilmaks. Kegagalan atau keberhasilan pemeran dalam berjuang menjadi bagian akhir di mana pondasi baru terbangun dan rutinitas kembali tercipta sebagai akibatnya.

Struktur yang disampaikan Adams (2007) sesuai dengan prinsip pertunjukan improvisasi long form di mana akhir dari cerita tidak tertentukan sebelumnya. Pemeran harus memainkan cerita dengan mengikuti aturan-aturan seperti yang telah dilatihkan dalam pelatihan improvisasi. Ditambah dengan aturan atau prinsip pertunjukan improvisasi. Ketidaktaatan akan aturan atau prinsip dapat membuat adegan atau dialog buntu dan berakhir dengan jalinan cerita yang kacau. Soal mendasar yang sering menjadi kendala pemeran adalah ego di mana ia selalu ingin tampil lebih baik daripada yang lain. Sementara dalam pertunjukan improvisasi prinsipnya adalah kebalikan; seroang pemeran harus membuat pemeran lainnya tampil dengan baik. Jika semua pemeran melalukan prinsip ini, maka semua pemeran akan tampil baik. Akan tetapi jika pemeran 
berprinsip menjadi yang terbaik di antara yang lain yang terjadi adalah hal yang sangat tidak diperkenankan dalam semua jenis pertunjukan teater yaitu perlombaan pemeranan dalam satu pementasan. Oleh karena itu, latihan improvisasi tidak bisa dilakukan sekali-kali. Selain membentuk pemahaman dan kemampuan, latihan improvisasi membentuk keterbukaan sikap pemeran terhadap pemeranan lain dan keberterimaan akan karakter yang harus ia perankan. Pertunjukan improvisasi bukanlah pertunjukan yang serta merta dilakukan tanpa persiapan dan latihan. Bukan pula sebuah pertunjukan yang dihadirkan hanya dengan memberikan arahan cerita singkat kepada para pemeran tanpa memahami aturan dan prinsip-prinsip improvisasi. Pertunjukan improvisasi yang baik akan terwujud ketika semua sudah dilatihkan dan dipersiapkan dengan baik pula. Semua pemeran bisa berperan dalam pertunjukan improvisasi, namun tidak semuanya bisa menampilkannya dengan baik, hanya pemeran yang terlatih baik dengan aturan dan prinsiplah yang bisa.

\section{Simpulan dan Penutup}

Latihan improvisasi berupa penggal adegan atau permainan sangat berguna bagi pemeran baik sebagai bekal dalam penerapan teknik pemeranan maupun pertunjukan improvisasi. Di sinilah letak singgungan utama improvisasi antara teknik pemeranan dan pertunjukan. Model, pola atau jenis latihan yang berada dalam kerangka aturan atau prinsip menjadi titik awal. Ketaatan aturan dalam berlatih menjadi kunci keberhasilan pemeran dalam menyerap materi pelatihan. Hampir semua elemen pemeranan dapat dilatihkan secara improvisasi. Dengan membuka penerimaan selebar mungkin pemeran dapat memperoleh pemahaman dan mampu mewujdukannya dengan baik. Diawali dari latihan improvisasi, pemeran dapat mengekspresikan dirinya dalam teater berbasis teks sebagai teknik improvisasi dan teater tanpa teks sebagai pertunjukan improvisasi.

Sebagai teknik pemeranan, improvisasi lebih condong pada spontanitas aksi fisik pemeran atas perubahan yang terjadi. Perubahan dapat dilihat secara mendalam melalui beat-beat dalam adegan. Setiap beat memiliki fokus tindakan tersendiri. Dengan kemampuan membedah adegan, membedakan beat serta memahami perubahan yang terjadi, dan menerapkannya berdasar fokus tindakan, pemeran dapat menampilkan laku aksi spontan dan alami tanpa harus mengubah baris kalimat dialog yang dituliskan pengarang. Sementara sebagai sebuah pertunjukan, pemeran akan memiliki kebebasan untuk mengekspresikan dirinya sesuai dengan prinsip dan struktur yang ditetapkan. Dalam pertunjukan improvisasi, pemeran akan mengoptimalkan kecakapan yang telah ia peroleh dalam rangakaian dan tahap pelatihan. Latihan improvisasi yang selalu dilakukan tanpa teks memudahkan pemeran berperan dalam teater tanpa teks. Struktur cerita yang dikolaborasikan dengan kecepatan berfikir yang dilandasai kejelasan tujuan berpadu dengan elemen justifikasi serta spontanitas yang dilakukan dengan memperhatikan prinsip penerimaan dan penolakan dalam membangun gagasan menjadi tulang punggung pertunjukan teater improvisasi. Semua hal tersebut dapat terwujud dengan baik hanya melalui latihan.

\section{Daftar Pustaka}

Adams, K. (2007). How to Improvise a FullLength Play, the Art of Spontaneous Theater. New York: Allworth Press.

Atkins, G. (1994). Improve! A Handbook for the Actor. Portsmouth: Heinemann.

Book, S. (2002). Book on Acting: Improvisation Technique for the Professional Actor in Film, Theater \& Television. Los Angeles: SilmanJames Press. 
Caird, J. (2010). Theatre Craft, A Director's Practical Companion from $A$ to $Z$. London: Faber and Faber Limited.

Cohen, L. (Ed.). (2010). The Lee Strasberg Notes. New York: Routledge.

Diggles, D. (2004). Improve for Actors. New York: Allworth Press.

Esper, W., \& DiMarco, D. (2008). The Actor's Art and Craft, William Esper Teaches the Meisner Technique. New York: Anchor Books.

Johnstone, Keith. 2014. Impro: Improvisation and Theatre. New York: Bloomsbury Publishing Plc.

Leep, Jeanne. 2008. Theatrical Improvisation Short Form, Long Form, and Sketch Based Improve. New York: Palgrave Macmillan.

Meisner, S., Longwell, D., \& Pollack, S. (1987). Sanford Meisner on Acting. New York: Vintage Books.

Rendra. 2013. Seni Drama Untuk Remaja. Bandung: Pustaka Jaya.

Santosa, Eko. 2014. "Teater dan Proses Hubungan Sosial: Sebuah Catatan Konsep Pelatihan Teater Studio Teater PPPPTK Seni dan Budaya Yogyakarta" dalam Proceedings International Seminar, Social Awareness in Arts Education. Yogyakarta: PPPPTK Seni dan Budaya.
Spolin, V. (1986). Theater Games for the Classroom, a Teacher's Handbook. Illinois: Nortwestern University Press.

Spolin, V. (1999). Improvisation for the Theatre. Illinois: Northwestern University Press.

Stanislavski, K. 2003. An Actor Prepares. New York: Routledge. 